KuLTura- MeDia-TeoLogia

ISSN 2081-8971

$2017 \mathrm{nr} 29$, s. 33-45.

\title{
Hejt jako zagrożenie wizerunku i pozycji rynkowej firm
}

Hate speech as a threat to the brand image and market position of companies.

\section{STRESZCZENIE:}

NOWYM, CORAZ BARDZIEJ POWSZECHNYM ZJAWISKIEM JEST HEJT POD ADRESEM FIRM, ZARÓWNO DUŻYCH GLOBALNYCH MAREK, JAK I MAŁYCH I ŚREDNICH PRZEDSIĘBIORSTW. AGRESYWNA, NIEUZASADNIONA KRYTYKA OSEABIA WIZERUNEK ATAKOWANYCH PODMIOTÓW GOSPODARCZYCH, PRZYCZYNIAJĄC SIĘ DO UTRATY ZAUFANIA KONSUMENTÓW I PARTNERÓW DO DANEJ MARKI. W PRZYPADKU NIEWIELKICH FIRM WPŁYWA TAKŻE NEGATYWNIE NA ICH POZYCJE EKONOMICZNĄ. NINIEJSZY ARTYKUŁ OMAWIA RÓŻNE FORMY TEGO ZJAWISKA ORAZ STRATEGIE, JAKIE OBIERAJĄ ZAATAKOWANE FIRMY.

SŁOWA KLUCZOWE: HEJT, WIZERUNEK MARKI, MEDIA SPOŁECZNOŚCIOWE

\begin{abstract}
:
NEW, INCREASINGLY COMMON PHENOMENON IS A HATE SPEECH AGAINST COMPANIES, LARGE GLOBAL BRANDS AS WELL AS SMALL AND MEDIUM-SIZED ENTERPRISES. AGGRESSIVE, UNJUSTIFIED CRITICISM WEAK THE IMAGE OF THE ATTACKED BRAND, WHICH LOSES THE TRUST OF CONSUMERS AND PARTNERS. ECONOMIC HATE SPEECH HAS ALSO A NEGATIVE IMPACT ON THE ECONOMIC POSITION OF SMALL BUSINESSES. THIS ARTICLE DISCUSSES THE CAUSES OF THIS PHENOMENON AND THE STRATEGIES OF DEFENSE OF THE ATTACKED COMPANIES.
\end{abstract}

\section{KEYWORDS:}

HATE SPEECH, BRAND IMAGE, SOCIAL MEDIA 
$\mathrm{Z}$ jawisko hejtingu (agresywnych, pozbawionych merytorycznych argumentów wypowiedzi online) jest rozpatrywane głównie w odniesieniu do osób publicznych (polityków, celebrytów ${ }^{1}$ ), przedstawicieli mniejszości (rasowych, etnicznych, seksualnych ${ }^{2}$ ), młodych użytkowników sieci społecznościowych ${ }^{3}$. Hejt najczęściej kojarzy się z działaniami mającymi innych skrzywdzić lub ośmieszyć, złośliwym przedstawianiem osób lub wydarzeń, szerzeniem języka nienawiści ${ }^{4}$.

Skala i skutki tego zjawiska skłoniły Komisję Europejską i największe przedsiębiorstwa technologiczne (Facebook, Twitter, YouTube, Microsoft) do przyjęcia w maju 2016 roku kodeksu postępowania, mającego ograniczyć rozprzestrzenianie się hejtu. W Polsce od kilku lat prowadzone są działania mające uświadamiać negatywne skutki hejtingu i zachęcać do zmiany postaw wobec niewłaściwych zachowań w sieci ${ }^{5}$.

Wspomniane inicjatywy koncentrują się na hejcie wymierzonym w osoby indywidualne, nieznane szerzej, bądź rozpoznawalne z racji wykonywanego zawodu czy aktywności społecznej. Hejt dotyka jednak także organizacje, instytucje, znane marki i niewielkie podmioty gospodarcze. Na przestrzeni kilku ostatnich lat obserwuje się coraz liczniejsze przykłady hejtingu wobec marek, celowej ich dyskredytacji poprzez agresywne i pozbawione argumentów merytorycznych wypowiedzi online, co przeradza się w sytuacje kryzysowe, rozgrywające się nie tylko w sieci, ale i świecie realnym ${ }^{6}$.

Wstępna analiza zagadnienia wskazuje, że hejting gospodarczy staje się coraz bardziej powszechny zagrażając wizerunkowi firmy, która została zaatakowana, osłabia zaufanie do niej, a nawet może być powodem jej upadku. Opierając się na studiach przypadku i wywiadach indywidualnych z przedstawicielami firm, specjalizującymi się w ochronie wizerunku przed działaniami hejterów, autorka szuka przyczyn tego zjawiska. Przedmiotem analizy jest także systematyzacja zachowań zaatakowanych marek.

1 M. Czaplicka, Hejt w Internecie. Raport ilościowy, strona internetowa wobuzz.com z września 2015, http://wobuzz.com/hejt/wp-content/uploads/2015/09/raport-o-hejcie-w-sieci.pdf (dostęp 20.09.2017).

2 M. Bilewicz, M. Marchlewska, W. Soral, M. Winiewski, Mowa nienawiści. Raport z badań Sondażowych, strona internetowa projektu Obywatele dla Demokracji, brak daty opubl.,

http://www.ngofund.org.pl/wp-content/uploads/2014/06/raport_final_poj.pdf (dostęp 22.09.2017).

$3 \quad$ J. Włodarczyk, Mowa nienawiści w internecie $w$ doświadczeniu polskiej młodzieży, strona internetowa mowanienawisci.info, brak daty opubl., http://www.mowanienawisci.info/wp-

content/uploads/2014/10/Mowa-nienawi\%C5\%9Bci-w-internecie-w-do\%C5\%9Bwiadczeniu-polskiej-m \%C5\%82odzie\%C5\%BCy.pdf (dostęp 10.10.2017).

4 Badanie SW Research „Kim jest hejter i co robi w sieci” przeprowadzone w dniach 27-28.07.2015 na 800 internautach w wieku 16-64 lata, próba losowo-kwotowa. Zob. (brak nazwiska autora), Hejterzy w sieci, strona internetowa firmy badawczej SW Research z 03.08.2015,

http://swresearch.pl/news/czytaj/id/110/hejterzy-w-sieci, (dostęp 20.09.2017).

5 M. in. kampanie Fundacji Dzieci Niczyje „Dodaj znajomego” i „Przytul hejtera”; kampania „Stop mowie nienawiści” Fundacji Batorego; kampania „HejtStop” Stowarzyszenia Projekt: Polska.

6 M. Kaczmarek-Śliwińska, Zarządzanie komunikacją kryzysową w przestrzeni mediów społecznościowych w kontekście zjawiska hejtingu, „Kultura-Media-Teologia” 2016 nr 25, s. 46-58. 


\section{Zjawiska towarzyszace komunikacji online}

Internet zmienił zasady komunikowania, umożliwił powstanie nowych zjawisk i narzędzi, pozwalających na szybkie i powszechne docieranie z informacją do potencjalnych odbiorców. Przyczynił się do zmiany postaw społecznych, zastąpienia konsumenta prosumentem - świadomym nabywcą, indywidualistą chcącym mieć wpływ na firmy, z usług i produktów których korzysta, ceniącego sobie wygodę, poszukującego aktywnie informacji o interesujących go markach ${ }^{7}$.

Dostępne w sieci źródła informacji - portale informacyjne, własne strony internetowe firm, media społecznościowe, grupy dyskusyjne, agregatory treści, porównywarki usług i produktów - pozwalają konsumentowi na dostęp w czasie rzeczywistym do informacji na temat produktu. Równocześnie ma on możliwość umieszczenia w sieci swojej oceny użytkowanego produktu, wrażeń związanych z kontaktem z daną marką, jakością oferowanej przez nią obsługi.

Z badań GUS wynika, że z internetu korzysta już dwie trzecie dorosłych Polaków (68\%), a 42\% wykorzystuje sieć do wyszukiwania informacji o produktach ${ }^{8}$. Opinie innych użytkowników sieci, także nieznanych im osobiście, są dla nich prawie tak ważne, jak opinie rodziny czy znajomych ${ }^{9}$.

Powszechność internetowych źródeł informacji i poziom zaufania do treści publikowanych w sieci w połączeniu z anonimowością ich nadawców, brakiem możliwości weryfikacji zamieszczanych danych i łatwością zestawiania ich w sposób dowolnie zmieniający wydźwięk daje duże możliwości nadużyć. Jak zauważa Ewa Hope, internet podważył na niespotykaną dotąd skalę wartości takie, jak prawda i szczerość: W internecie manipulacja i kłamstwo stały się integralną częścią działań, uznano za naturalne zjawiska, które były do tej pory naganne jak ukrywanie swojej tożsamości w trakcie wypowiedzi ${ }^{10}$.

O możliwościach działań manipulacyjnych w sieci pisze także Monika Kaczmarek-Śliwińska, omawiając zjawiska mimikry i mimezji komunikacyjnej online ${ }^{11}$. Pierwsza z tych form komunikacji to działania podejmowane przez podmioty o ukrytej lub fałszywej tożsamości, których celem jest wywołanie określonego zachowania (zakupu produktu, skorzystania z usługi) lub przekonania adresatów przekazów do zmiany poglądów, poparcia idei lub osoby. Do działań tego typu można zaliczyć nieautentyczne komentarze, posty, dyskusje chwalące firmy, jak i dyskredytujące ich konkurentów.

Mimezja komunikacyjna online polega na wytworzeniu fałszywego środowiska komunikowania, działającego na rzecz określonej marki lub dyskredytującego inną,

\footnotetext{
A. Miotk, Nowy PR. Jak internet zmienił public relations, Lublin 2016, s. 97-110. Mały Rocznik Statystyczny Polski 2016, GUS, Warszawa 2016, s. 257.

9 R. Wolny, Internet jako źródło informacji e-konsumentów o ofercie handlowej i usługowej przedsiębiorstw, „Zeszyty Naukowe Wyższej Szkoły Bankowej we Wrocławiu” 2015, nr 3, s, 407-415.

1 E. Hope, Etyka w zawodzie specjalistów public relations, Warszawa 2013, s. 125.

11 M. Kaczmarek-Śliwińska, Mimikra i mimezja komunikacyjna jako formy nieetycznej komunikacji online, w: A. Baczyński, M. Drożdż (red.), Wartość mediów - od wyzwań do szans, Tarnów 2012, s. 313-328.
} 
upodobnienia go do środowiska znanego internautom, a następnie zaproszenia użytkowników do kontaktu. Przykładem wykorzystania mimezji są fałszywe blogi, nieautentyczne fan page'e, antywitryny.

Należy jednak pamiętać, że internet jako narzędzie komunikacji sam w sobie nie generuje nieetycznych działań, stwarzając jedynie możliwości dla zachowań nagannych $^{12}$. Zjawiskiem sprzyjającym werbalnej agresji w sieci jest opisane przez Adama Joinsona zachowanie rozhamowane lub niestłumione (disinhibited behaviour), określane jako podejmowanie w sieci działań, na które użytkownik - ze względu na mechanizmy kontroli społecznej - nie zdecydowałby się w świecie rzeczywistym ${ }^{13}$.

\section{Wpływ hejtu na organizację}

Wizerunek rozumiany jako znaczenie marki dla nabywców stanowi jedno ze źródeł jej siły ${ }^{14}$. W procesie jego budowania ważną rolę odgrywają reputacja i zaufanie. Firma ciesząca się dobrą reputacją (wypracowaną w przeszłości) jest przez odbiorców postrzegana jako godna zaufania, szacunku, przewidywalna ${ }^{15}$. Dla odbiorcy dobry wizerunek pełni funkcję orientacyjną, oznacza minimalizację ryzyka podjęcia błędnych decyzji, dotyczących zakupu produktu danej marki, wyboru jej na partnera biznesowego lub podjęcia w danej firmie pracy. Zwłaszcza w sytuacji, gdy odbiorca nie jest w stanie obiektywnie ocenić jakości oferty danej marki wizerunek staje się najważniejszym kryterium zastępczym $^{16}$.

Do grup wpływu na wizerunek Krystyna Wojcik zalicza stan organizacji, intensywność i jakość komunikowania o nim oraz odbiór, rezonans społeczny organizacji ze strony jej grup otoczenia ${ }^{17}$. Na jakość i intensywność komunikowania mają wpływ m.in. wiarygodność organizacji oraz zaufanie odbiorców do niej, natomiast odbiór kształtowany jest na podstawie czynników racjonalnych (wiedzy odbiorców na temat organizacji i doświadczeń z nią związanych), emocjonalnych (odczuć, oczekiwań, obaw, sympatii i antypatii związanych oraz niezwiązanych z daną organizacją) i społecznych (norm obowiązujących w grupach, z którymi odbiorcy czują się związani, kształtującymi ich poglądy i oceny).

Wizerunek jest kształtowany pod jednoczesnym wpływem czynników z tych trzech grup, co oznacza, że o postrzeganiu marki decyduje nie tylko to, jaka ona jest w rzeczywistości, ale także jakie wiadomości na jej temat trafiają do odbiorców, jaki jest ich kontekst społeczny i jakie ona skojarzenia wywołuje. Siła skojarzeń składających się na wizerunek marki decyduje otym, jakie informacje na jej temat są przywoływane

\footnotetext{
E. Hope, dz. cyt., s. 126.

J. M. Zając, Materiały do kursu „Wykorzystanie Internetu w badaniach społecznych”, Warszawa 2007, s. 9-10.

14 R. Kłeczek, Silna marka z punktu widzenia nabywcy, w: Kall J., Kłeczek R., Sagan A. (red.), Zarządzanie marką, Warszawa 2013, s. 19-22.

15 E. Hope, dz. cyt., s. 36-38.

16 K. Wojcik, Public relations. Wiarygodny dialog z otoczeniem, Warszawa 2005, s.194-196.

17 Tamże, s. 38-43.
} 


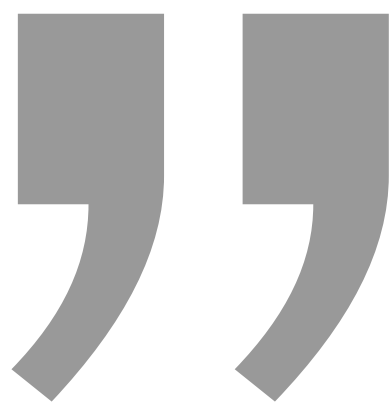

\section{Duże marki, przeznaczające znaczne budżety} na działania marketingowe online i korzystające z usług wyspecjalizowanych firm, są w stanie dotrzeć w sieci do osób potencjalnie zainteresowanych ich oferta, a takize w czasie rzeczywistym monitorować treści pojawiające się na ich temat, odpowiadać klientom w mediach społecznościowych, reagować na bieżąco na syǵnały o problemach z produktem lub
usłuǵą chroniąc wizerunek marki.

przez odbiorcę stykającego się z nazwą marki ${ }^{18} \mathrm{i}$ wpływa na ich zachowania wobec niej. Im więcej źródeł, z których te skojarzenia pochodzą tym są one silniejsze ${ }^{19}$.

W czasach przed cyfrową rewolucją marki miały znacznie większą kontrolę nad przekazem na ich temat i wpływ na to, jak są postrzegane. Rozwój internetu dał im szerokie możliwości dotarcia do odbiorców, dzięki niższym kosztom działań marketingowych i wielości kanałów komunikacji. Jednocześnie spowodował utratę kontroli nad treściami, które na ich temat są publikowane. Dzięki nowym technologiom każdy użytkownik sieci może stać się aktywnym uczestnikiem procesu komunikowania jako nadawca treści bądź uczestnik społecznego modelu ich dystrybucji poprzez komentowanie, modyfikowanie i dalsze udostępnianie informacji. W internecie, a zwłaszcza w mediach społecznościowych odbiorca poszukuje treści, które są dla niego ciekawe, ważne, przydatne: przekaz jest ściśle powiązany z indywidualnymi preferencjami odbiorcó $w^{20}$. Konsument zdecydowany na zakup produktu z danej kategorii, bądź potrzebujący dostawcy potrzebnej mu usługi, szuka w sieci szczegółowych informacji na ten temat i opinii innych użytkowników, z reguły nie weryfikując prawdziwości tych komentarzy. Duże marki, przeznaczające znaczne budżety na działania marketingowe online i korzystające z usług wyspecjalizowanych firm, są w stanie dotrzeć w sieci do osób potencjalnie zainteresowanych ich ofertą, a także w czasie rzeczywistym monitorować treści pojawiające się na ich temat, odpowiadać klientom w mediach społecznościowych, reagować na bieżąco na sygnały o problemach z produktem lub usługą chroniąc wizerunek marki.

18 K. L. Keller Strategic Brand Management: Building; Measuring, and Managing Brand Equity, Upper Sadle River 1998, cyt. za: R. Kłeczek, dz. cyt., s. 22.

19 Zob. R. Kłeczek, dz. cyt., s. 22-27.

20 D. Kaznowski, Social media, wehikuł percepcji społecznej, white paper, czerwiec 2011, https://networkeddigital.files.wordpress.com/2011/07/e-book-social-media-dominik-kaznowski.pdf (dostęp: 10.10.2017), s.12. 


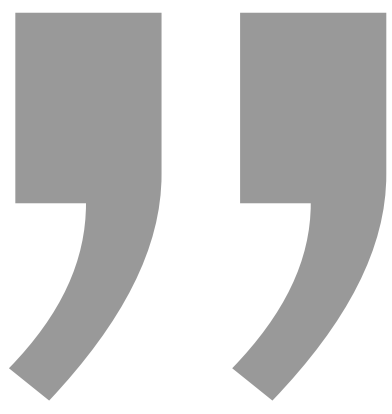

\section{Jeśli negatywna opinia ma charakter krytyki} konsumenckiej lub reklamacji, zawiera udokumentowane fakty i rzeczowe argumenty, wówczas firma ma szansę odnieść się do takiej oceny, wyjaśnić okoliczności i w przypadku reakcji zgodnej ze standardami obsługi klienta (przeprosiny, zadośćuczynienie) ma możliwość zyskać przychylną ocenę konsumentów oraz wzmocnić swój wizerunek. Natomiast obraźliwe, agresywne atakowanie firmy w sieci buduje negatywne skojarzenia z marka, niszczy korzyści symboliczne z nią związane (....).

Mniejsze firmy nie mają na to zasobów kadrowych i finansowych, a często także świadomości jak ważna jest aktywna obecność w sieci i interakcja z odbiorcami. Może to prowadzić do sytuacji, gdy źródłem wiadomości na temat marki i czynnikiem decydującym o jej odbiorze społecznym - zwłaszcza gdy jest to pierwszy kontakt odbiorcy z marką stają się twórcy negatywnych przekazów.

Jeśli negatywna opinia ma charakter krytyki konsumenckiej lub reklamacji, zawiera udokumentowane fakty i rzeczowe argumenty, wówczas firma ma szansę odnieść się do takiej oceny, wyjaśnić okoliczności i w przypadku reakcji zgodnej ze standardami obsługi klienta (przeprosiny, zadośćuczynienie) ma możliwość zyskać przychylną ocenę konsumentów oraz wzmocnić swój wizerunek. Natomiast obraźliwe, agresywne atakowanie firmy w sieci buduje negatywne skojarzenia z marką, niszczy korzyści symboliczne z nią związane ${ }^{21}$, powoduje dodatkowe wydatki na działania związane z ochroną dobrego imienia ${ }^{22}$, a w przypadku małych i średnich firm, których funkcjonowanie w dużej mierze opiera się na renomie, może prowadzić do utraty klientów i zachwiania stabilności finansowej ${ }^{23}$.

21 Odpowiadające na pytanie: w jaki sposób marka X może poprawić lub pogorszyć akceptacjęjej nabywcy przez innych. Zob. R. Kłeczek, dz. cyt. s. 21.

R. Burn-Callander, Bad reviews and online "trolls" cost UK businesses up to £30,000 a year, strona internetowa "The Telegraph" $\mathrm{z}$ 29.05.2015,

http://www.telegraph.co.uk/finance/businessclub/11635195/Bad-reviews-and-online-trolls-cost-UK-businesses-up-to-30000-a-year.html, (dostęp 10.10.2017).

Zob. S. Czubkowska, Hejt na firmy winternecie: im większy, tym lepszy biznes, portal forsal.pl z 08.08.2016, http://forsal.pl/artykuly/965896, hejt-na-firmy-w-internecie-im-wiekszy-tym-lepszy-biznes.html, (dostęp 25.09.2017); M. Suchodolska, Gospodarczy hejt, czyli jak doprowadzić konkurenta do 
Nie są to jednostkowe przypadki. Ponad połowa (52\%) brytyjskich firm badanych przez Igniyte, firmę zajmującą się zarządzaniem reputacją online, w ciągu ostatniego roku odnotowała straty wywołane przez publikacje w sieci, zaś $79 \%$ badanych ocenia, że opinie, komentarze i posty na forach i w mediach społecznościowych są ważne dla sytuacji finansowej i reputacji ich przedsiębiorstw. Badani wskazują także na rosnące znaczenie internetowych treści dla bieżącej działalności firm, konieczność monitorowania sieci i zarządzania negatywnymi treściami, co wiąże się z dodatkowymi obowiązkami pracowników i nakładami finansowymi ${ }^{24}$.

\section{Hejt gospodarczy - systematyka zjawiska}

Analizując hejt w odniesieniu do marek warto przywołać typologię zaproponowaną przez Monikę Kaczmarek-Śliwińską, która wskazała na trzy czynniki, istotne dla opisu zjawiska hejtingu:

\section{tematyka, związana ze stopniem relacji grup otoczenia i podmiotu hejtingu:}

- tematy zwykle mniej kontrowersyjne, interesujące wąską grupę odbiorców w otoczeniu wewnętrznym,

- tematy angażujące szeroką społeczność w otoczeniu zewnętrznym, potencjalnie większe ryzyko wystąpienia sytuacji kryzysowej;

\section{podmiot lub przedmiot hejtingu:}

- $\quad$ koncentrujący się jedynie na podmiocie/przedmiocie konkretnej sprawy,

- wychodzący poza podmiot/przedmiot konkretnej sprawy, budzący zainteresowanie liczniejszych grup społeczności i zwiększający ryzyko wystąpienia sytuacji kryzysowej;

tożsamość „autorów” hejtingu:

- $\quad$ podmioty anonimowe - typowe dla zjawiska mimikry i mimezji komunikacyjnej online,

- osoby o tożsamościach autentycznych i fałszywych,

- $\quad$ osoby nieznane szerokiej społeczności, liderzy opinii oraz osoby znane szerokiej publiczności (celebryci, politycy, dziennikarze itp. ${ }^{25}$.

W przypadku hejtu gospodarczego można wyróżnić treści odwołujące się do racjonalnych i emocjonalnych czynników kształtujących wizerunek oraz treści wywołanych przez czynnik społeczny.

W pierwszym przypadku dominują treści anonimowych autorów lub osób posługujących się fałszywymi tożsamościami. Dotyczą one wewnętrznego funkcjono-

ruiny, internetowe wydanie „Gazety Prawnej” z 07.03.2014,

http://biznes.gazetaprawna.pl/artykuly/782473,gospodarczy-hejt-czyli-jak-doprowadzic-konkurenta-do-ruiny.html, (dostęp 25.09.2017).

24 T. Johnson, Igniyte Research: Trolls have damaged half of British businesses' reputations, strona internetowa Igniyte z 24.10.2016, https://www.igniyte.com/en/blog/2016/10/igniyte-research-trolls-have-damaged-half-of-british-businesses-reputations/ (dostęp 20.10.2017).

25 M. Kaczmarek-Śliwińska, Zarządzanie komunikacją kryzysową..., art. cyt. s. 9-10. 
wania organizacji lub jakości produktu/usług oferowanych przez firmy. Hejt pod adresem pracodawcy (dotyczący płacy, kwestii socjalnych, relacji interpersonalnych, terminowości regulowania zobowiązań wobec pracowników), rozpowszechniany głównie na forach internetowych i w specjalistycznych serwisach, jest interesujący dla otoczenia wewnętrznego (obecni i potencjalni pracownicy) i nie angażuje szerokiej publiczności. Charakteryzuje się ogólnikowymi oskarżeniami, brakiem konkretów, wysokim poziomem agresji, niecenzuralnym słownictwem i stosowaniem ataków ad personam.

Weryfikacja takich treści jest praktycznie niemożliwa, podobnie zresztą, jak hejtu atakującego firmę ze względu na oferowany produkt lub usługę, zamieszczanego w porównywarkach ofert, na forach tematycznych i lokalnych portalach. Brak możliwości weryfikacji oskarżeń oraz identyfikacji nadawcy treści rodzi podejrzenie o celowe działania wymierzone w te podmioty. Na coraz bardziej konkurencyjnym rynku pozyskanie nowego konsumenta, szczególnie przez firmy zaczynające działalność, wymaga sporych nakładów na reklamę i marketing, długiego budowania zaufania. Znacznie tańsze i prostsze, choć etycznie naganne, jest niszczenie reputacji konkurenta za pomocą metod stosowanych od dawna w świecie polityki ${ }^{26}$ - zdyskredytowanie go za pomocą rozpowszechnianych online insynuacji lub nieuzasadnionej, obraźliwej krytyki.

Szczególnie szybko zdobywają popularność i zasięg liczony w setkach tysięcy odbiorców oskarżenia klientów pod adresem firm z sektora FMCG, zwłaszcza producentów żywności. Agresywne wpisy, przypisujące markom złe intencje, działanie niezgodne z przepisami lub brak dbałości o jakość produktów, często pisane są w emocjach, bez próby wyjaśnienia problemu u bezpośrednio zainteresowanych ${ }^{27}$.

Do tematów angażujących szeroką publiczność, osiągających bardzo duży zasięg w krótkim czasie należą treści hejterskie związane z cechami marki lub jej działaniami, które są niezgodne z poglądami danej grupy społecznej, bądź w ocenie jej przedstawicieli uderzają w wartości ważne dla tej grupy. Na takie ataki narażone $\mathrm{są}^{28}$ :

- firmy medialne, reprezentujące wyraziste stanowisko w kwestiach politycznospołecznych (np. „Gazeta Wyborcza”, „Gazeta Polska”),

- firmy z obcym kapitałem (w Polsce szczególnie z kapitałem niemieckim, np. tytuły koncernu Polska Press),

- firmy angażujące do działań marketingowych osoby zaangażowane po jednej ze stron walki politycznej, głoszące kontrowersyjne poglądy lub które popełniły czyn, godzący w normy społeczno-obyczajowe (np. Empik krytykowany za kampanię marketingową z udziałem Marii Czubaszek czy firma odzieżowa Bytom,

26 M. Karwat, O złośliwej dyskredytacji. Manipulowanie wizerunkiem przeciwnika, Warszawa 2006, s. 1315 .

27 I. Leć, Szczura w kaszce nie było. Czy Nestlé zażąda rekompensaty?, portal kurierlubelski.pl z 17.03.2013, http://www.kurierlubelski.pl/artykul/784038,szczura-w-kaszce-nie-bylo-czy-nestle-zazada-rekompensaty,id,t.html (dostęp 23.10.2017).

28 Opr. własne. 
wykorzystująca w reklamie wizerunek Daniela Olbrychskiego, wielokrotnie zatrzymywanego za jazdę pod wpływem alkoholu),

- firmy, których przedstawiciele (właściciele, osoby zarządzające) prezentują poglądy niezgodne z wartościami danej grupy (np. browar Ciechan),

- firmy, których produkt/usługa godzi w wartości/poglądy danej grupy (np. Maspex, producent napoju Tiger).

Autorami hejtingu tego typu są w przeważającej części osoby z określoną tożsamością, zarówno nieznane szerokiej społeczności, jak i pełniące funkcję liderów opinii dla danej grupy społecznej. Treści te są publikowane w social media, następnie przetwarzane przez media tradycyjne i komentowane ponownie na forach internetowych tych mediów oraz na ich profilach społecznościowych. Taka forma dystrybucji powoduje lawinowy wzrost liczby komentarzy i bardzo duży zasięg negatywnych treści. Często towarzyszą im wezwania do rezygnacji z korzystania z produktów marki, a nawet deklaracje bojkotu konsumenckiego, które jednak nie znajdują potwierdzenia w danych sprzedażowych ${ }^{29}$.

Analizując reakcje zaatakowanych firm, można wyróżnić kilka typów zachowañ ${ }^{30}$ :

- ignorowanie ataków, wynikające z braku świadomości ich pojawienia się lub świadomej strategii, opierającej się na założeniu, że szkalujące treści nie mają znaczenia. Brak reakcji przyczynia się do osłabienia wizerunku, zaś w przypadku dużej skali zjawiska zagraża podstawom funkcjonowania organizacji, powodując odpływ klientów, pracowników i partnerów biznesowych, wewnętrzną destabilizację, mniejsze przychody, wzmożone kontrole ${ }^{31}$

- aktywna dyskusja, próba merytorycznej rozmowy z atakującymi. Rzadko przynosi pożądane rezultaty, atakujący nie odnoszą się do argumentów, reakcja marki wyzwala dodatkowe wpisy i podsyca temperaturę dyskusji, powodując frustrację osób identyfikujących się z marką ${ }^{32}$

- $\quad$ wycofanie się z działań wywołujących ataki, prowadzenie aktywnej komunikacji kryzysowej zgodnie z modelem 5P (przyznaj się do błędu, przeproś, przeciwdziałaj eskalacji kryzysu, powetuj straty, popraw się) ${ }^{33}$

29 T. Borejza, Dlaczego bojkoty konsumenckie nie działają w Polsce, portal marketingprzykawie.pl, brak daty publ., https://marketingprzykawie.pl/artykuly/dlaczego-bojkoty-konsumenckie-nie-dzialaja-w-polsce/ (dostęp 24.10.2017).

30 Opr. własne.

31 M. Suchodolska, Gospodarczy hejt, czyli jak doprowadzić konkurenta do ruiny, art., cyt.

32 Przykładem jest krytyka marki Rossman, po publikacji w wydawanym przez nią miesięczniku „Skarb” krytycznych artykułów poświęconych rządowemu programowi 500+. Zobacz: https://www.facebook.com/RossmannPL/posts/640612002765002.

33 W przypadku Tesco rezygnacja z billboardu wywołującego gwałtowne komentarze internautów uspokoiła sytuację, $w$ przypadku producenta napoju Tiger podręcznikowa reakcja marki nie zatrzymała fali hejtu. Por. bg, Tesco wycofuje reklamę z kobieta w ciąży podającą posiłek mężczyźnie, portal wirtualnemedia.pl z 11.10.2017, http://www.wirtualnemedia.pl/artykul/tesco-wycofuje-reklame-z-kobieta-w-ciazy-podajaca-posilek-mezczyznie, (dostęp 24.102017); J. Kotarbiński, Marka wyklęta, portal marketingprzykawie.pl z 18.08.2017 https://marketingprzykawie.pl/artykuly/marka-wykleta/, (dostęp 24.10.2017). 
- mobilizacja zwolenników, skuteczna w przypadku istnienia zbudowanej w przeszłości lojalnej grupy ambasadorów, silnie związanych z marką, identyfikujących się z reprezentowanymi przez nią wartościami ${ }^{34}$

- rozbrojenie sytuacji poprzez żart, pokazanie dystansu. Możliwe jedynie na początkowym etapie pojawiania się treści, które są atrakcyjne dla ograniczonej grupy odbiorców. Gdy atak nie ma charakteru masowego, agresor zwykle poddaje się widząc, że jego działania nie robią wrażenia

- usuwanie szkalujących treści poprzez zwrócenie się do administratora portalu o zablokowanie dostępu do wpisów. Część serwisów (zwłaszcza porównywarki ofert i portale dedykowane opiniom użytkowników) umożliwia zgłaszanie niewłaściwych treści, a nawet ich samodzielne kasowanie pod warunkiem uiszczenia opłaty. Stawki i procedura dokonania wpłaty są łatwe do znalezienia na stronie $^{35}$

- kroki prawne podejmowane samodzielnie lub z pomocą wyspecjalizowanych podmiotów na podstawie kodeksu karnego oraz kodeksu cywilnego ${ }^{36}$ skierowane wobec administratorów stron lub autorów wpisów. Możliwe jest dochodzenie na drodze sądowej usunięcia obraźliwych wpisów, przeprosin, finansowego zadośćuczynienia za poniesione straty lub utracone korzyści.

We wszystkich opisanych strategiach obowiązuje ta sama zasada - im szybsza reakcja, tym prawdopodobieństwo zatrzymania ataku jest większe. To oznacza, że w rzeczywistości nowej, sieciowej komunikacji, skuteczna ochrona marki wymaga wsparcia zaawansowanych narzędzi monitorowania internetu i reagowania na zasadzie real-time.

\section{Podsumowanie}

Precyzyjne określenie skali hejtingu gospodarczego wymagałoby przeprowadzenia szerokich badań ilościowych. Od roku 2013 na polskim rynku powstało kilkadziesiąt firm i kancelarii prawnych, zajmujących się ochroną reputacji online. Co roku notują one wzrost liczby klientów i prowadzonych postępowañ ${ }^{37}$, wywołanych przez oszczerstwa konkurencji lub opinie niezadowolonych klientów bądź byłych pracowników. W przypadku małych firm utrata wirtualnej reputacji może wywołać odpływ klientów, a nawet doprowadzić firmę do bankructwa. Duże marki są bardziej odporne na ataki hejterów, jednak nie lekceważą nawet małych rys na wizerunku podejmując działania z zakresu

34 P. Kalisz, „Jesteśmy ofiarą”. Tygodnik Powszechny prosi o pomoc po ataku nacjonalistów, portal natemat.pl brak daty publikacji, http://natemat.pl/187411,jestesmy-ofiara-tygodnik-powszechny-prosi-o-pomoc-po-ataku-nacjonalistow, (dostęp 21.10.2017).

ieckszy, tym lepszy biznes, art. cyt.

Szerzej o kwalifikacji prawnej w odniesieniu do aktów hejtingu pisze M. Kaczmarek-Śliwińska, Zarządzanie komunikacją kryzysową..., art. cyt., s. 48-49.

37 Informacje na podstawie indywidualnych wywiadów pogłębionych przeprowadzonych przez autorkę w dniach 26-30.09.2016 z przedstawicielami 10 firm: kancelarii prawnych oraz firm zajmujących się ochroną wizerunku podmiotów gospodarczych, marek oraz osób prywatnych w internecie. 
komunikacji kryzysowej mające ograniczyć zasięg ataku, czy też walcząc z nieuczciwą konkurencją na drodze prawnej i usuwając z sieci nieprawdziwe informacje.

Nowym zjawiskiem jest hejting na tle społeczno-politycznym, skierowany przeciwko markom, symbolizującym lub reprezentującym wartości/poglądy odmienne od autorów obraźliwych treści. Tego typu ataki charakteryzują się dużą intensywnością i angażują szerokie kręgi odbiorców, zarówno w mediach społecznościowych, jak i tradycyjnych, relacjonujących dyskusję w internecie.

Rosnąca skala zjawiska hejtu gospodarczego wynika także $\mathrm{z}$ cech charakterystycznych dla nowych mediów. W internecie na dużą skalę możliwa jest publikacja anonimowych opinii użytkowników bez wcześniejszej weryfikacji. Nieobecność gatekeeperów, brak odpowiedzialności użytkowników za słowo, niewystarczająca wiedza na temat działania nowych mediów, to czynniki sprzyjające rozwojowi zjawiska hejtu gospodarczego.

\section{BIBLIOGRAFIA}

bg, Tesco wycofuje reklamę z kobieta w ciąży podającą posiłek mężczyźnie, portal wirtualnemedia.pl z 11.10.2017, http://www.wirtualnemedia.pl/artykul/tesco-wycofuje-reklame-z-kobieta-w-ciazy-podajaca-posilek-mezczyznie, (dostęp 24.10.2017);

Bilewicz M., Marchlewska M., Soral W., Winiewski M., Mowa nienawiści. Raport z badań

Sondażowych, strona internetowa projektu Obywatele dla Demokracji, brak daty opubl., http://www.ngofund.org.pl/wpcontent/uploads/2014/06/raport_final_poj.pdf (dostęp 22.09.2017).

Borejza T., Dlaczego bojkoty konsumenckie nie działają w Polsct, portal marketingprzykawie.pl, brak daty publ., https://marketingprzykawie.pl/artykuly/dlaczego-bojkoty-konsumenckie-nie-dzialaja-w-polsce/ (dostęp 24.10.2017).

Burn-Callander R., Bad reviews and online "trolls" cost UK businesses up to $£ 30,000$ a year, strona internetowa "The Telegraph" z 29.05.2015, http://www.telegraph.co.uk/finance/businessclub/11635195/Badreviews-and-online-trolls-cost-UK-businesses-up-to-30000-a-year.html, (dostęp 10.12.2017).

Czaplicka M., Hejt w Internecie. Raport ilościowy. http://wobuzz.com/hejt/wp-content/uploads/2015/09/raport-o-hejciew-sieci.pdf (dostęp 20.09.2017).

Czubkowska S., Hejt na firmy w internecie: im większy, tym lepszy biznes, portal forsal.pl z 08.08.2016, http://forsal.pl/artykuly/965896, hejt-na-firmy-w-internecie-im-wiekszy-tym-lepszy-biznes.html, (dostęp 25.09.2017). 
Hejterzy $w$ sieci, strona internetowa firmy badawczej SW Research z 03.08.2015, http://swresearch.pl/news/czytaj/id/110/hejterzy-w-sieci, (dostęp 20.09.2017).

Hope E., Etyka w zawodzie specjalistów public relations, Warszawa 2013. Johnson T., Igniyte Research: Trolls have damaged half of British businesses' reputations, strona internetowa Igniyte z 24.10.2016, https://www.igniyte.com/en/blog/2016/10/igniyte-research-trollshave-damaged-half-of-british-businesses-reputations/ (dostęp 20.11.2017).

Kaczmarek-Śliwińska M., Mimikra i mimezja komunikacyjna jako formy nieetycznej komunikacji online, w: A. Baczyński, M. Drożdż (red.), Wartość mediów - od wyzwań do szans, Tarnów 2012, s. 313-328.

Kaczmarek-Śliwińska M., Zarządzanie komunikacją kryzysową w przestrzeni mediów społecznościowych w kontekście zjawiska hejtingu, „Kultura-Media-Teologia” $2016 \mathrm{nr}$ 25, s. 46-58.

Kalisz P., „Jesteśmy ofiarą'. Tygodnik Powszechny prosi o pomoc po ataku nacjonalistów, portal natemat.pl brak daty publikacji,

http://natemat.pl/187411,jestesmy-ofiara-tygodnik-powszechny-prosi-opomoc-po-ataku-nacjonalistow, (dostęp 21.10.2017).

Karwat M., O złośliwej dyskredytacji. Manipulowanie wizerunkiem przeciwnika, Warszawa 2006.

Kaznowski D., Social media, wehikuł percepcji społecznej, white paper, czerwiec 2011, https://networkeddigital.files.wordpress.com/2011/07/e-book-social-media-dominik-kaznowski.pdf (dostęp: 10.10.2017).

Keller K.L. Strategic Brand Management: Building, Measuring, and Managing Brand Equity, Upper Sadle River 1998.

Kłeczek R., Silna marka z punktu widzenia nabywcy, w: Kall J., Kłeczek R., Sagan A. (red.), Zarządzanie marką, Warszawa 2013, s. 15-35.

Kotarbiński J., Marka wyklęta, portal marketingprzykawie.pl z 18.08.2017. https://marketingprzykawie.pl/artykuly/marka-wykleta/, (dostęp 24.10.2017).

Leć I., Szczura w kaszce nie było. Czy Nestlé zażąda rekompensaty?portal kurierlubelski.pl z 17.03.2013,

http://www.kurierlubelski.pl/artykul/784038,szczura-w-kaszce-nie-bylo-czy-nestle-zazada-rekompensaty,id,t.html (dostęp 23.10.2017).

Mały Rocznik Statystyczny Polski 2016, GUS, Warszawa 2016.

Miotk A., Nowy PR. Jak internet zmienił public relations, Lublin 2016.

Suchodolska M., Gospodarczy hejt, czyli jak doprowadzić konkurenta do ruiny, internetowe wydanie „Gazety Prawnej” z 07.03.2014, http://biznes.gazetaprawna.pl/artykuly/782473,gospodarczy-hejt-czyli-jak-doprowadzic-konkurenta-do-ruiny.html, (dostęp 29.09.2017). 
Włodarczyk J., Mowa nienawiści w internecie $w$ doświadczeniu polskiej młodzieży, strona internetowa mowanienawisci.info, brak daty opubl., http://www.mowanienawisci.info/wp-content/uploads/2014/10/Mowanienawi\%C5\%9Bci-w-internecie-w-do\%C5\%9Bwiadczeniu-polskiej-m \%C5\%82odzie\%C5\%BCy.pdf (dostęp 10.10.2017).

Wojcik K., Public relations. Wiarygodny dialog z otoczeniem, Warszawa 2005.

Wolny R., Internet jako źródło informacji e-konsumentów o ofercie handlowej i usługowej przedsiębiorstw, Zeszyty Naukowe Wyższej Szkoły Bankowej we Wrocławiu 2015, nr 3, s. 407-415.

Zając J. M., Materiały do kursu „Wykorzystanie Internetu w badaniach społecznych", Warszawa 2007.

\section{O AUTORCE:}

Urszula Podraza - trener, menedżer z kilkunastoletnim doświadczeniem w zarządzaniu komunikacją, doradca medialny. Specjalizuje się $w$ działaniach dotyczących strategii wizerunkowych, zarządzaniu kryzysem, public affairs. Jest autorką książki poświęconej kryzysowemu public relations oraz kilkudziesięciu artykułów naukowych i publicystycznych dotyczących wizerunku instytucji i marek.

Kontakt: www.linkedin.com/in/urszulapodraza/ 